Makale türü / Article type: Araştırma / Research

\title{
Partileşme Sürecinde İdeolojik Söylem: Demokrasi ve Atılım Partisi ve Gelecek Partisi Programlarında Adalet ve Kalkınma Partisi Eleştirisi
}

\author{
$* * *$ \\ Ideological Discourse in the Process of Partying: Justice and Development Party (AK Parti)
Criticism In Democracy and Progress Party's (DEVA) and the Future Party Programs
}

\author{
Dr. Öğr. Üyesi Hacı Hasan Saf \\ Sivas Cumhuriyet Üniversitesi, İletişim Fakültesi, hasansaf@cumhuriyet.edu.tr \\ ORCID: 0000-00002-7778-0258
}

\begin{abstract}
Özet
Modernleşme süreci ile artan siyasal katılım, insan haklarının genişlemesi ve bireylerin yönetimde daha fazla söz sahibi olması gibi unsurlar demokratik ortamı geliştirmiş, bu da siyasal partilerin önemini artırmıştır. Siyasi partilerin siyasal açıdan birer güç unsuru haline gelmesi, partileşme sürecini niceliksel olarak geliştirmiştir. Bu konu hakkında kriz teorisi, parlamento dışında doğan partiler, kuşaksal yaş ve fonksiyon gibi yaklaşımlar ortaya atılmıştır. Partileşme sürecinde gerçekleştirilen ideolojik söylem ise partilerin neyi eleştirdiğini, kurumsal kimliklerini ve yukarıda bahsedilen hangi yaklaşım çerçevesinde partileştiklerini ortaya koymaktadır. Bu durumdan hareketle ülkemizde partileşme sürecinde olan Demokrasi ve Atılım (DEVA) Partisi ile Gelecek Partisi'nin ideolojik söylemi nasıl araçsallaştıııldığının incelenmesi araştırmanın amacını oluşturmaktadır. Çalışmada Demokrasi ve Atılım (DEVA) Partisi ile Gelecek Partisi'nin parti programları iktidarı eleştiri ve kendi ideolojisini söylemleştirme çerçevesinde Foucaultcu Söylem Analizi yöntemi ile analiz edilmiştir. Demokrasi ve Atılım (DEVA) Partisi'nin hem iktidar muhafazakarlığını eleştirerek hem de kendi ideolojisini araçsallaştırarak ideolojik söylem inşa ettiği görülmüştür. Gelecek Partisi’nin programında ise yalnızca iktidar eleştirisinin varlığından söz edilmektedir.
\end{abstract}

Anahtar Kelimeler: Partileşme süreci, İdeolojik söylem, Foucaultcu Söylem Analizi.

JEL Sinıflandırması: D72, P48

\begin{abstract}
Increasing political participation with the modernization process, the expansion of human rights and the fact that individuals have more say in management have developed the democratic environment, which has increased the importance of political parties. The political parties becoming an element of political power have quantitatively improved the process of partyization. Approaches such as crisis theory, parties born out of parliament, generational age and function have been introduced. The ideological discourse made in the process of partying reveals what the parties criticized, their institutional identities and within which framework they were partying. Based on this situation, the purpose of the research is to examine how the Democracy and Progress Party's (DEVA) and the Future Party are instrumentalized in the process of partyization in our country. In the study, the party programs of the Democracy and Progress Party's (DEVA) and the Future Party were analyzed by Foucauldian Discourse Analysis method in the framework of criticizing the power and discourse of its own ideology. It was seen that the Democracy and Progress Party's (DEVA) built ideological discourse both by criticizing the conservatism of political power and instrumentalizing its own ideology. In the program of the Future Party, only the critique of power is mentioned.
\end{abstract}

Keywords: The process of partying, Ideological discourse, Foucauldian Discourse Analysis

JEL Classification: D72, P48 


\section{GİRIŞ}

Demokrasinin yerleşmeye başlaması çeşitli koşullar altında gerçekleşmiştir. Modernleşme, katılımın artması, bireylerin hak ve özgürlüklerinin tanımlanması bunlardan yalnızca bazılarıdır. Bu unsurların yanında demokrasinin siyasal yaşamda da gün yüzüne çıkması için siyasal partilerin kurulması ve kurumsallık adına partileşmesi önemlidir. Bu çerçevede değerlendirildiğinde ülkemizde partileşme sürecinde bulunan Demokrasi ve Atılım (DEVA) Partisi ile Gelecek Partisi'nin, partileşme teorileri ekseninden bakıldığında kriz teorisi, parlamento dışında doğan partiler, kuşaksal yaş ve fonksiyon yaklaşımlarına benzer şekilde ortaya çıktıkları görülmektedir.

Demokrasinin gereklerinden olan partileşme sürecinde gerçekleştirilen ideolojik söylem, hem partinin ideolojik konumunun seçmenlere duyurulması hem de kurumsallığın gerçekleştirilmesi için önemli bir yer tutmaktadır. Toplumu şekillendirmek adına inşa edilen ve toplum içerisinde de dönüşümler yaşayan söz dizisi olarak adlandırılabilecek söylemin siyasal anlamda toplumları harekete geçirmek için temellendirilen ideoloji ile kaynaşmasıyla ortaya çıkan ideolojik söylem ise hem siyasal iktidar hem de muhalif unsurlar tarafından araçsallaştırılmıştır. Yeni kurulan ve partileşme sürecinde olan DEVA Partisi ve Gelecek Partisi de ideolojik söylemi iletişim çalışmalarında kullanmışlardır. Daha çok Adalet ve Kalkınma Partisi (AK Parti) içerisinde yer alıp görev yapan siyasilerden kurulan DEVA Partisi ve Gelecek Partisi'nin ideolojik söylemi nasıl konumlandırdıkları ise bilinmemektedir.

Çalışmada partileşme sürecinde inşa edilen ideolojik söylemin çözümlenmesi amaçlanmıştır. Bu amaçtan hareketle DEVA Partisi ve Gelecek Partisi'nin parti programları analiz edilmiştir. Örneklemin analizinde iktidar ve muhalif unsurları barındırmasından dolayı söylemi iktidar ilişkileri çerçevesinde açıklayan Foucaultcu Söylem Analizi (FSA) yöntem olarak kullanılmıştır. Analizde aşağıdaki hipotezler sınanmıştır:

H: DEVA Partisi ideolojik söylemi daha çok AK Parti muhafazakârlığına eleştiriler çerçevesinde inşa edilmiştir.

$\mathrm{H}_{2}$ : DEVA Partisi ideolojik söylemi daha çok liberal demokrasinin temel ilkeleri çerçevesinde inşa edilmiştir.

H3: Gelecek Partisi ideolojik söylemi daha çok AK Parti muhafazakârlı̆̆ına eleştiriler çerçevesinde inşa edilmiştir.

H: Gelecek Partisi ideolojik söylemi daha çok muhafazakârlı̆̆ın temel ilkeleri çerçevesinde inşa edilmiştir.

Her iki parti programı da demokrasi, hukuk, siyaset, ekonomi, toplum, teknoloji, kültür sanat ve spor, güvenlik, dış politika ve çevre olmak üzere on başlık altında toplanmıştır. Bu konu başlıkları çerçevesinde gerçekleştirilen analiz sonucunda $\mathrm{H}_{1} \mathrm{H}_{2}$ ve $\mathrm{H}_{3}$ hipotezleri kabul edilmiş, $\mathrm{H}_{4}$ hipotezi ise reddedilmiştir.

\section{PARTILEŞME SÜRECINDE TEMEL YAKLAŞIMLAR VE DEMOKRASİ VE ATILIM PARTISI ILLE GELECEK PARTISI' NIN KONUMU}

Demokrasinin gereği olarak ortaya çıkan ve temsil ile katılım açısından değerli görülen partileşme süreci, çeşitli yaklaşımlar çerçevesinde değerlendirilmektedir. Bu yaklaşımlar modernleşme teorisi, kriz teorisi, seçim dönemi ve parlamento durumu ile parti tipolojisi olarak karşımıza çıkmaktadır. Bu başlık altında DEVA Partisi ile Gelecek Partisi'nin kuruluş süreci yukarıda bahsedilen yaklaşımlar perspektifinde tartışılacaktır.

Siyasal egemenliğin aristokrasi, oligarşi ve teokrasi benzeri yönetimlerde olduğu gibi sınırlı bir toplumsal gruba tesis edildiği ülkelerde, toplumun geri kalanının iktidarda söz sahibi olmadığı ortadadır. İktidarın, egemenliğin ve onun kaynaklarının toplumun tamamına sunulduğu ülkelerde ise bireylerin iktidara talip olma ve siyasal katılım için birleştiği, çeşitli organizasyonlar kurduğu görülmektedir. Bu nedenle 
egemenliğin ve iktidarın toplumun tamamı tarafından ulaşılabilir olduğu inancı herkes tarafından kabul görmelidir. Bu çerçevede genel oy ilkesi ile temel insan hakları ve özgürlüklerin toplumca kabulü, siyasi partilerin kurulmasında ve gelişerek ilerlemesinde önemli bir rol oynamaktadır (Dursun, 2014: 253).

Siyasi partilerin kuruluşlarıyla ilgili birçok teori ortaya atılmıştır, bunların ilki modernleşme teorisidir. Modernleşme teorisine göre partilerin ortaya çıkışı, yer aldığı toplumda meydana gelen modernleşmenin bir gereğidir. Kuruluş aşamalarının gerçekleştiği toplumda modernleşme süreci tam olarak tamamlanmamışsa siyasi partilerin işlevsel bir etkinliğinden söz edilememektedir (Dursun, 2014: 255). Ülkemizde özellikle kuruluş süreciyle modernleşme adına gerçekleşen çalışmalar, çok partili yaşama geçme çabalarını da içerisinde barındırmaktadır. Askeri darbeler ve parti kapatmalar gibi çeşitli modernleşmeye aykırı çatışmalarla kesintiye uğrayan demokratikleşme hedefi, gelişmekte olan bir ülke olarak Türkiye Cumhuriyeti'nde tam olarak gerçekleştirilememiştir. Modernleşme teorisi çerçevesinde modernleşmeyi demokrasi açısından tanımlayan kriterlere (medyanın ekonomi-politiği, medya içeriğinde ideoloji, siyasi ayrımcılık ve yurttaşların siyasal özgürlüğü gibi) de bakıldığında yeni kurulan partiler olan DEVA Partisi ile Gelecek Partisi'nin siyasal hayata katıldığı ortam, bu teori açısından sorunludur. Her iki parti de AK Parti'nin içerisindeki politikacılar tarafından kurulduklarından ve direkt olarak iktidar partisine rakip olarak görüldüklerinden iktidara yakın medya kuruluşları tarafından içeriğe dahil edilmemektedirler. Daha çok sosyal medya unsurları çerçevesinde gerçekleşen siyasal iletişim çalışmaları da geniş kitlelere ulaşamamaktadır.

Modernleşme teorisi kapsamında değerlendirilecek bir diğer unsur da partilerin finansman durumudur. Ülkemizde siyasal partilerin finansmanı, bağışlar, üye aidatlarından ve Hazine ve Maliye Bakanlığı ödeneğinden karşılanmaktadır. Ancak bakanlık ödeneği \%10’luk seçim barajını geçen partilere ödenmektedir. Bu da yeni kurulan ve mecliste geniş temsil firsatı bulamayan partiler için rekabet açısından sorun teşkil etmektedir. Böylece Türkiye Büyük Millet Meclisi (TBMM) içerisinde bir milletvekili bulunan DEVA Partisi ve TBMM'de temsil edilmeyen Gelecek Partisi'nin bu teori çerçevesinde modernleşme teorisine uymayan süreçlerle meydana geldiği söylenebilir.

Siyasi partilerin kuruluşuna etki ettiği düşünülen bir diğer yaklaşım da toplumsal bunalımlardır. $\mathrm{Bu}$ çerçevede sunulan görüşler kriz teorileri olarak karşımıza çıkmaktadır. Siyasi meşruluk bunalımı (krizi), siyasal katılım bunalımı ve bütünleşme bunalımı; kriz teorilerini açıklamak için ortaya atılmış alt başlıklardır (Dursun, 2014: 256-257). Meşruluk krizine bakıldığında, bir toplumda ülkeyi kimin yöneteceği konusundaki fikir ayrılığının oluşması bu krizin nedeni olarak karşımıza çıkmaktadır. Bu durumun temelinde ülkeyi yönetenlerin yönetim konusundaki beceri ve bilgisinin düzeyi ile egemenliğin asıl kaynağ 1 olan halkın gözündeki meşruluk durumu yatmaktadır. Bahsedilen iki sorunun da görüldüğü, toplumda bu yönde yaygın bir kanının oluştuğu ülkelerde meşruluk krizi var denilebilir. Böylesi bir siyasal ortamda gerçekleşen yeni bir parti kuruluşu, meşruluk krizine dayandırılmaktadır. Siyasal katılım bunalımının ise, siyasal sisteme (ve dolayısıyla egemenlik ve iktidar ortaklığına) müdahil olmak isteyen birey veya toplumsal grupların siyasiler tarafından meşru görülmeyip kabul edilmemeleri sonucunda ortaya çıkan bir çatışma veya kriz olarak tanımlandığı görülmektedir. Bu teoriye göre bir ülkede ve toplumda demokrasinin gereği yerine getirilir ve siyasal sisteme katılamayan birey veya gruplara verilen medeni ve siyasi haklar yaygınlaşmaya başlarsa, siyasal katılım bunalımı yaşayan bireyler birleşerek bir siyasi parti kurma sürecine girip siyasal sisteme dahil olmaktadırlar. Bütünleşme bunalımında ise toplumun büyük bir kesimini benimseyemeyen onunla bütünlük sağlayamayan, herhangi bir ortak fikirde buluşamayan ve kendisini kapatan bir kesimden ve siyasi çevreden bahsedilmektedir. Bu teori çeşitli din, dil ve ırk gruplarından bir ulus devlet çıkarma çabasının yaşadığı zorlukları açıklamak adına kullanılmaktadır (Dursun, 2014: 257).

Bahsedilen bunalımlar çerçevesinde değerlendirildiğinde özellikle ülkemizde cumhurbaşkanlığı sistemine geçildikten sonra yürütmeyle ilgili tartışmalar, DEVA Partisi ve Gelecek Partisi tarafindan dile getirilmektedir. $\mathrm{Bu}$ durum da partileşme sürecindeki meşruluk bunalımına karşılık gelmektedir. Siyasal 
katılım bunalımı kapsamında bakıldığında ise Gelecek Partisi Genel Başkanı Ahmet Davutoğlu, başbakanken istifa etmiş ve bu durumun kendisi dışarısında gerçekleşen durumlardan kaynaklandığını ifade etmiştir. Bu da siyasal katılım bunalımının yaşandığını göstermektedir. Son olarak bütünleşme bunalımı her iki yeni partinin de iktidarın kucaklayamadığı, temsil edemediği çevreler olduğundan bahsettiği şekliyle karşımıza çıkmaktadır.

Yukarıda bahsedilen parti kuruluş teorilerinin yanı sıra M. Duverger'in seçim dönemlerinde ve parlamentolarda doğan partiler ile parlamento dışından çıkan partiler ayrımı da literatürde yer almaktadır. $\mathrm{Bu}$ yaklaşıma göre seçim zamanlarında ve parlamentolarda doğan partiler, karşımıza diğer partilerden daha önce çıkmışlardır. Bu tip partilerin ortaya çıkışı da öncelikle parlamentodaki parti gruplarının kurulması ve onu takiben aralarında bağlantı kuran seçim komitelerine dayanmaktadır. Kurulan ilksel parlamento grupları da genel anlamda yerel birlikteliklerden meydana gelmiştir. Daha sonraları parlamento grupları aralarına yerel olmayan üyeleri de almaya çalışarak temsil kapsamı kazanma yoluna gitmişlerdir. Yerel etkenlerin haricinde bireyler çıkarların da grupların kurulmasında rolü vardır. Yalnız başına seçilme amacı ve kaygısı taşıyan adaylar, gruplara dahil olarak gruplarıyla birlikte yeniden seçilme olanaklarını daha kolay görmüşlerdir (1974: 16-31).

Parlamento dışarısında doğan partilere bakıldı̆̆ında ise daha farklı bir tablo ile karşılaşılmaktadır. Bu yaklaşıma göre bir parti seçim sürecinde ve parlamento dışında bulunan kurumların etkisiyle oluşmuşsa buna kısmen parlamento dışından doğmuş parti denilebilmektedir. Kesin bir yargı söz konusu değildir; çünkü parlamento içerisinde doğan partilerde de dişarıdan bir kurumun etkisi olabilmektedir. Buradaki genel ayrım, eğilimler esas alınarak incelendiğinde, daha doğru sonuçlara varılabilmektedir (Duverger, 1974: 16-31). DEVA Partisi ve Gelecek Partisi kurucularına ve üyelerine bakıldığında TBMM içerisinde yalnızca DEVA Partisi'nin bir milletvekili (Mustafa Yeneroğlu) bulunmaktadır. Bu da her iki partinin parlamento dişında doğmuş partiler olduğunu göstermektedir.

Bilindiği üzere parti tipleri, siyasi partilerin sınıflandırılması için hazırlanmış ayrımlardır. Bu ayrımlar; partilerin yapı, ideoloji ve örgüt anlayışı gibi açıklardan incelenmesinde yardımcı olmaktadır. Bunlardan en önemlisi M. Duverger (1998: 256) tarafindan ortaya atılan "kadro" ve "kitle" partileri tipolojisidir. Daha sonraları Sigmund Neumann (1942: 89)'a ait olan "temsil partileri ve bütünleşme partileri” ile Otto Kircheimer (1969: 55)'in ortaya attığ1 "hepsini yakala partileri" gelmektedir. Bunların yanında Panebianco'nun "profesyonel partiler" tipolojisi, Katz ve Mair (2009: 89)'in "kartel partiler" tipolojisi ve Ruud Koole (2009)'ye ait olan "modern kadro partileri” tipolojisi de siyaset biliminde kullanılan diğer tipolojiler olarak bilinmektedir.

Duverger (1998: 90)'in yaptığı kadro ve kitle partileri ayrımında kadro partileri, parlamento içinden çıkan, üye sayısından çok niteliğine önem atfeden, faaliyetlerini yoğunlukla seçim zamanlarında gerçekleştiren partilerdir. Bahsedilen nitelikten kasıt, parti üyelerinin parasal açıdan güçlü ve siyasal nüfuzlu kişilerden seçilmesidir. Parti finansmanının çoğunlukla bu zengin üyelerin bağış ve yardımlarından sağlanması söz konusudur. Kitle partileri ise parlamento dışarısında ortaya çıkan geniş kitlelere sahip partilerdir. Finansmanın bu geniş kitlelerin oluşturduğu üyelerden aldıkları aidatlarla sağlayan kitle partilerinde üyeler, yalnızca mali yönden değil siyasi nüfuz açısından da önem taşımaktadır. Kitle partilerinin ideolojik yapıları daha belirgindir ve mevcut üyelerini de bu ideolojiler çerçevesinde eğitip yetiştirme faaliyetlerinde bulunmaktadırlar. "Örgütlenme faaliyetlerine bakıldığında kitle partilerinin merkeziyetçi ve disiplinli, katı bir hiyerarşik örgütlenmeye sahip oldukları görülmektedir” (Kapani, 2019: 169-170).

Parti tipolojileri çerçevesinde bakıldığında DEVA Partisi ve Gelecek Partisi'nin henüz seçime girmediği ve seçmen nezdinde kabul görüp görmediklerinin bilinmediği söylenebilir. Bu açıdan her iki parti de kitle partisi olma özellikleri açısından değerlendirilememektedir. Ancak her iki parti kurucu, yönetici ve üyeleri daha çok AK Parti kadroları içerisinden çıktığından kadro partisi olarak değerlendirilebilir. 
Huntington'a göre siyasal örgütlerin güç, istikrar ve zayıflıkları kurumsallaşmalarıyla ilintilidir. Kurumsallaşmayı, "örgütlerle usullerin itibar ve istikrar kazanmaları süreci” olarak tanımlayan düşünür, bir siyasal sistemin kurumsallaşma durumunun o sistemdeki örgüt ve usullerin adapte edilebilirliği, karmaşık yapısı, özerkliği ve tutarlılığı ile ölçülebildiğini ifade etmektedir (1965: 65).

Huntington'ın ölçütlerinden bir partinin kurumsallaşması süreci üç açıdan incelenebilir. Bunlar: partinin kronolojik yaşı, kuşaksal yaşı ve fonksiyonudur. Yaş çerçevesinden bakıldığında bir partinin ne kadar süredir varlığını sürdürüyorsa o kadar kurumsallaştı̆̆1 söylenebilmektedir (1965: 65). Köklü partilerin ileride de varlığını sürdüreceğine dair inanç, yeni kurulan bir partinin ileride varlığını sürdüreceğine olan inançtan daha fazladır. Çünkü bir siyasi parti, varlığını devam ettirdiği süre dahilinde çeşitli sorunları aşmış olmaktadır. Bu durum da kurumsallaşmayı güçlendirmektedir. Kuşaksal yaş ölçütüne bakıldığında ise Huntington, bir partinin yönetici ve lider kadrosundaki bireyler hala o partinin kurucu kadrosu ise bu partinin adaptasyonunun şüpheli olduğunu ifade etmektedir (1965: 67).

Huntington'a göre siyasal partiler, birtakım sivil toplum örgütleriyle, toplumsal gruplarla ve unsurlarla ilişkili olabilirler. Fakat bir siyasi parti siyasi ortamda, yalnızca belli toplumsal veya sivil toplum unsurunun hakları çerçevesinde siyaset yapıyorsa kurumsallaşmada sorun olduğu söylenebilmektedir. Çünkü siyasal partilerin siyasal amaçlar açısından yalnızca halkın geneli için çalışması gerekmektedir, bu da fonksiyonu tasvir etmektedir (1965: 73-75).

Yaş çerçevesinden bakıldığında DEVA Partisi ve Gelecek Partisi yeni kurulan partilerdir. Bu nedenle kuşaksal yaş açısından da değerlendirildiğinde kurucuların hala genel başkanlar ve yöneticiler olduğu görülmektedir. Fonksiyon açısından ise henüz siyasal olarak yönetime gelemeyen partilerin değerlendirilmesi zor olacaktır, bu nedenle söylemler analiz edilmelidir. Bu da çalışmanın son bölümünde incelenecektir.

Görüleceği üzere partileşme sürecinde siyasal partilerin konumu çeşitli yaklaşımlar çerçevesinde değerlendirilmektedir. Bu yaklaşımlar kapsamında bakıldığında DEVA ve Gelecek Partisi’nin konumunun kriz teorisi, parlamento dışında doğan partiler, kuşaksal yaş ve fonksiyon yaklaşımlarına benzer olduğu görülmüştür.

\section{2. İDEOLOJIK SÖYLEM}

Siyasal partilerin partileşme sürecinde kendi amaç ve fikirlerini kitlelere duyurma adına gerçekleştirdiği siyasal iletişim çalışmalarında söylem, önemli bir yer tutmaktadır. Kitleleri ikna etmek için gerçekleştirilen söylemlerde, parti ideolojisinin duyurulması ve parti kimliğinin de bu yolla inşa edilmesi hemen her yeni siyasal parti için sıradan görülmektedir. Bu başlık altında ideoloji ve söylem kavramlarından oluşan ideolojik söylem kavramı tartışılacaktır.

İdeoloji birey, grup ya da toplumu harekete geçiren fikirler bileşeni olarak tanımlanabilmektedir. "Sosyal hayattaki anlam, gösterge ve değerlerin üretim süreci; belli bir toplumsal grup veya sınıfa ait fikirler kümesi veya inanç sistemi; egemen bir siyasi iktidarı meşrulaştırmaya yarayan fikirler; sistemli bir biçimde çarpıtılmış iletişim; söylem ve iktidarın çatışması ideolojidir" (Türk, 2003: 106-107). İdeolojiyi "grup fikirleri” olarak tanımlayan Hartley, ideolojinin cinsiyetten (kadın-erkek ideolojisi), çalışmaya (meslek ideolojisi) kadar uzanan sınıf fikirlerini içerdiğini belirtmektedir (2002: 103-104). Yaşamın her alanının ideolojinin işleme, üretim ve biçimlendirme sahası olduğu söylenebilir.

Bazı düşünürler ideolojiyi söylem, argüman, imaj ve yargı gibi belli bir amaca ulaşmaya çalışan ve belli grup veya aktörler eliyle yönetilen bir dizi sembolik unsurlar, bazıları da belirli bir sosyo-politik sistemi karakterize eden genel geçer olgular biçiminde tanımlamaktadırlar. İlk yaklaşıma "izm" olarak ifade edebileceğimiz liberalizm, faşizm, komünizm, anarşizm ve Marksizm, Leninizm, Maoizm, Stalinizm ile belirli ekoller, doktrinler (Truman Doktrini, Monroe Doktrini, Chicago Okulu, Frankfurt Okulu gibi) 
girmektedir. Ayrıca muhafazakâr, ilerici ve ırkçı gibi bir siyasal sistem içerisindeki belli fikriler de birinci yaklaşıma dahil edilebilmektedir. Bu ideolojiler kendilerine bağlı unsurları karakterize etmektedir. Örneklendirmek gerekirse, liberal bir birey bu ideolojiyi benimsemiştir, sosyalist olarak tanımlanan kişi sosyalist dünya anlayışına bağlıdır. Birinci yaklaşımdaki ideoloji anlayışı partizanlığı ve buna bağlı görüşleri temsil etmektedir. İkinci yaklaşımın tanımı ise daha zordur. Bu tür bir ideoloji belirli bir sosyopolitik sistemin kültürel ve fikirsel boyutunu ifade etmektedir. Bu unsurlar bir var oluşu, yapıyı ve tarihsel dönüşümleri karakterize eden büyük anlatılardır (Blommaert, 2005: 158-159).

İdeoloji bu çalışma kapsamında siyasal partilerin araçsallaştırdığı unsurlar olarak ele alınmaktadır. Siyasal ideolojiler; temelde komünizm, faşizm, sosyalizm, sosyal demokrasi ve muhafazakârlık olarak sıralanabilir. Söylem ise karmaşık yapıya sahip olmasına rağmen bu çalışma kapsamında ideolojinin iletilmesi için kullanılan tasarlanmış söz dizisi olarak betimlenebilmektedir.

Söylem terimi köken açısından Latince'de "discurrere" (koşuşturma) kelimesinden, ve/veya "uzaklaşma", "eritme", "yayılma" anlamındaki "discursus" kelimesinin çeşitli anlamlarına karşılık gelmektedir. Mecazi olarak da "özne hakkında uzun uzadıya konuşma”, "bir şey hakkında iletişim kurma” anlamındadır (Sözen, 1999: 19).

Kıran ve arkadaşları (2001: 277) söylemi, "söz", "metin", "sözce" kavramlarını da içerisine alan bir terim olarak değerlendirmektedir. "Bu terim "söz" (F. De Saussure), ya da "sözce" (L. Bloomfield) kavramlarına göndermede bulunmadığı zaman, öğeleri kendi bağıntılar bütünüyle tanımlanan, bitmiş kapalı bir yapı anlamında aşağı yukarı "metne" eşdeğerdir." Ancak kavram basite indirgenemeyecek kadar karmaşık ve komplikedir.

Foucault'ya göre söylem yalnız başına değil, bütüncül ve üretimi ile birlikte analiz edilebilir hale gelmektedir. Bir söylemin anlaşılması ise söylemi üreten, artıran ve istikrarlı hale getiren iktidar (yanında muhalefet) ve kurumlar aracılı̆̆ıyla mümkün olmaktadır. Ona göre söylem, "görevi onun gücünü ve tehlikelerini önlemek, belirsiz olagelişini dizginlemek, ağır korkulu maddiliğini savuşturmak olan birtakım yollarla, hem denetlenmiş hem ayıklanmış hem de örgütlenmiş ve yeniden paylaştırılmıştır" (Foucault, 1993: 9-10). Kısaca belli bir amaç çerçevesinde inşa edilen söylem, siyasal erkler tarafindan siyasal bir amaç için de kullanılmaktadır.

Söylem, toplumsal bir pratik olarak karşımıza çıkmaktadır. Bu çerçevede taraf veya tarafsılılı̆ın ifadesi, yöneltilen suçlamalar, kültürel alanlardaki insan ilişkilerini ifade eden eylemlerin, pratiklerin gerçekleşmesi olarak değerlendirilebilir. Bireyler gündelik yaşantılarındaki tutum, davranış, inanç, fikir gibi birçok konuyu söylem pratikleriyle ortaya koymaktadır. Bu açıdan da toplumsal bir pratik olan söylem, bireylerin hayata ilişkin tanımlamaları, anlamasında önemli bir rol oynamaktadır (Portter, 2004: 71-72).

Söylemsel pratikler, yalnızca söylem üretim biçimleri değildir. Bu pratikler, teknik bütünlerde, kurumsal unsurlarda, davranış kalıplarında, iletişim ve yayın temalarında, bu pratikleri kabul ettiren ve yürüten pedagojik formlarda karşımıza çıkıp söylemi nesnelleştirmiştir. Bir söylemsel pratiğin değişimi çoğunlukla karmaşık bir değişimler bütününe ilintilidir. Bu değişimler, söylemsel uygulamaların dışında (üretim formlarında, toplumsal ilişkilerde, siyasal kurumlarda, kavramların içinin boşaltılıp yeniden doldurulmasında, öteki söylemsel pratiklerde, bilgilerin toplanıp bir araya getirilmesinde) ortaya çıkabilmektedir. Ancak söylemsel pratikler, bu unsurları kesin bir sonuç olarak değil, kendi yapısal bütünlüğünü koruyan bir etki ve kendini dönüştürene oranla belli bir işlevler topluluğu olarak bağlidır (Foucault, 2015: 43-44).

Foucault (1987: 23)'ya göre: “söylemin üretimi, her toplumda, görevleri onun gücünü ve tehlikelerini önlemek, belirsiz olagelişlerini dizginlemek, ağır, korkulu maddiliğini savuşturmak olan birtakım yollarla, hem denetlenmiş hem ayıklanmış, hem de örgütlenmiş ve yeniden paylaştırılmıştır". Yani sistematik ve planlanmış bir sürecin sonucunda ortaya çıkan söylem, siyasal gücün de tekelindedir. 
Yaşamın her alanında birey ve toplumun karşısına çıkan söylem, hem toplumu şekillendirmekte hem de toplum içerisinde çeşitli değişim ve dönüşüme uğramaktadır. Topluma nüfuz eden söylem, ideoloji ile inşa edildiğinde siyasal olarak partiler tarafından araçsallaştırılmaktadır. Söylem, ideoloji ile ayrılmaz bir bütün oluşturarak ideolojik söyleme dönüşmektedir.

Eagleton (2011: 257)'1n da belirttiği üzere "Her söylemsel süreç ideolojik ilişkilere içkindir ve bu ilişkilerin baskısıyla içeriden biçimlenir. Dilin kendisi işçi ve burjuvanın, kadın ve erkeğin, idealist ve materyalistin aynı şekilde paylaştı̆̆1, görece özerk bir sistemdir." Söylemle ideoloji arasındaki ilişkiye vurgu yapan Eagleton (2011: 255-257)'a göre, ideolojiye dair genel yaklaşımlar "bilinç" ve "fikir" düzeyinde olmakla birlikte idealist bir perspektifte ele alınmaktadır. Böylelikle de "bilinç" söylemsel uygulamalardan kopan bir parça olmaktadır. Düşünür, ideolojiyi cisimsiz fikirler ve belirli davranış kalıplarıyla ilgili bir durum olarak görmekten çok ideolojinin söylemsel veya göstergesel bir fenomen olarak görmektedir.

İdeolojik olmayan söylem ve söylemsel olmayan ideoloji söz konusu değildir. Her ideolojinin ve söylemin anlam inşa mücadelesinde baskıcı bir iktidar olma olasılığı mevcuttur. Kitle iletişim metinlerinde ideoloji ve söylem "toplumsal anlamların belirlenmesi alanındaki mücadele" (Hall, 1998: 166) olarak tanımlanmaktadır.

Van Dijk (1995a: 18) ideolojilerin genel olarak söylemlerle aktarıldığını ve söylemlerle yeniden üretildiğini ifade etmektedir. İdeolojiyi, bir grubun bilişsel sosyo-politik fikirlerinin bilişsel temelini oluşturan bir sistem bütünü olarak tanımlayan Van Dijk (1995b: 138), ideolojik söylem analizinin amacının ideolojik temel yapılarla söylem yapıları arasındaki bağlantıyı sistematik ortaya koymak olduğunu ortaya atmaktadır (1995b: 143). Van Dijk (2000: 88) bunların yanında, ideoloji ve söylem arasındaki ilişkinin çift yönlü olduğunu, ideolojilerin söylemleri saptarken söylemlerin de ideolojileri kabul etmemize veya değiştirmemize sebep olduğunu belirtir. Bu çalışmada, Van Dijk (1989: 27)'1n “ikna edici söylem” diye tanımladığı türden söylemler daha çok medya içeriği olarak sunulmakta ve izleyicinin eylemlerini etkilemeyi amaçlamaktadır. Söylemler yoluyla ideolojilerin benimsenmesi (Van Dijk 2006: 133-134) bakımından söylemler önemli işlevsel olmaktadır.

Görüleceği üzere toplumu siyasal olarak harekete geçirme adına ikna aracı olarak inşa edilen ideoloji, toplumsal norm ve kurumları da belirleyen söylemi amacına ulaşmak için araçsallaştırmaktadır. Böylece karşımıza ideolojik söylem kavramı çıkmaktadır. İdeolojik söylem ise hem iktidarlar hem de onlara muhalefet olarak karşımıza çıkan partiler tarafından kullanılmaktadır.

\section{DEVA PARTISI VE GELECEK PARTISI PROGRAMLARI ÜZERİNE BİR ARAŞTIRMA 3.1. Araştırmanın Konusu, Sorunu ve Amacı}

Partileşme sürecindeki yaklaşımlar açısından değerlendirildiğinde konumları tespit edilen DEVA ve Gelecek Partisi, çalışmanın daha önceki başlıklarında da önemi ortaya koyulan ideolojik söylemi araçsallaştırmıştır. Daha çok iktidarda bulunan AK Parti kadrolarında yer alan politikacılar tarafından kurulan DEVA ve Gelecek Partisi, farklı söylemler geliştirse de genel olarak muhafazakârlık ve liberalizm ideoloji çerçevesinde inşa edilmişlerdir. Bu nedenle öncelikle ülkemizde muhafazakâr ideolojinin konumu incelenmelidir.

Muhafazakârlık, herhangi bir ideolojik yaklaşıma karşı olarak inancını "bir zihinsel durum" veya bir "hayat görüşü” olarak ifade etmeyi tercih etmektedir. Muhafazakârlığın anlaşılması en zor argümanlarından biri, terimin bilinen anlamıyla bir ideoloji olmamasıdır. Buradaki çelişki, muhafazakârlı̆̆ın ideolojik teorileri reddeden bir teori olmasıdır (Özipek, 2011: 164). Bu çerçevede muhafazakârlık, genel geçer bir siyasal duruş, düşünce tarzı ya da ideoloji olduğu konusunda hala konsensüse varılamamış; fakat tek başına farklı bir ideoloji olarak ele alınması gereken bir kavramdır (Erler, 2007: 126; Erdoğan, 2014: 4). En genel tanımlamayla muhafazakârlık, mevcut statükonun korunmasını savunan ve amaçlayan, bir değişim gerçekleşecekse de bunun saf doğal süreçlerle şekillenmesinin zorunluluğunu vurgulayan, dişa ve 
kendisinden farklı unsurlara bağlı toptan değişikliklere karşı olan (Erler, 2007: 127) bir düşünce biçimi ya da bir siyasal tavirdır.

Böylesi bir duruma karşın kendisinden önceki örneklere de bakıldığında AK Parti farklı bir konumlandırma stratejisi geliştirmiştir. Daha önce sıkça kapatılma tehlikesi yaşayan muhafazakâr partiler olan Refah ve Fazilet Partisi içerisindeki politikacılar (Recep Tayyip Erdoğan, Abdullah Gül ve Bülent Arınç) tarafindan kurulan AK Parti, kendisinden önceki radikal söylemleri geride bırakarak daha kapsayıcı ve uyumlu bir anlayış sergilemiştir. Bu da laik cumhuriyet dinamiklerine ve kurucu ilkelere sert eleştiri getirilmemesini içermektedir.

AK Parti’nin Kemalist-laik siyaset içerisinde yer alması, parti açısından demokrasi ısrarını barındırırken; Kemalist siyaset açısından ise laiklik kaygılarını yükselten gerilimli bir ortamı doğurmuştur. Toplumsal uzlaşma ve kaynaşma söylemleri ile siyasete ve kendi seçmenine yeni çıkış yolları açmaya çalışan AK Parti; dinin kamu yönetiminden çıkmasını ifade eden tanımlayıcı laikliğe karşı, İslami-muhafazakâr ve liberal çevre ile birlikte dinsel unsurların kamusal ve yönetimsel hayatta alan kazanma ya da devlet otoritesince müdahaleye maruz kalmaksızın yaşanabilirliğini iddia eden pasif laikliği desteklemiştir (Kuru ve Stepan, 2013: 108).

Radikal olmayan laikliğe doğru siyasi yakınlık, AK Parti muhafazakârlı̆̆ının değerlendirmesinde "muhafaza etmekten" çok "karşı tavrında" yeni tanımlamaları karşımıza çıkarmaktadır. Kendiliğinden ve evrimci bir dönüşümden yana ve sosyal mühendisliğe aykırı bir tavır sergilenmiştir. Böylece AK Parti'nin savunduğu muhafazakâr demokratlık, "toplumsal merkezi kavrayan" bir üslup olarak tanımlanarak devlet ve toplum arasındaki ilişkiyi parti-birey ilişkisine dönüştürebilmiştir (Özbudun \& Hale, 2010: 64-65).

Bu uyum ve yumuşama söylemleri yalnızca birer siyasal iletişim unsuru ve çalışması olmaktan çıkarılarak hükümet çalışmalarında da tatbik edilmiştir. Söylemler parti programlarında kalmayarak hükümet politikalarında da uygulamaya geçirilmiştir.

Dönemin başbakanı Recep Tayyip Erdoğan parti kimliğini ilan ederken muhafazakâr demokrasiyle ilgili şu ifadeleri kullanmıştır (59. Hükümet Programı, 2003):

“... muhafazakârlık, katı ve donmuş bir ideolojiden çok demokrat bir perspektifi temsil etmektedir. Demokrasi, milli iradenin kabulüne mazhar olarak, siyasal iktidarın meşruluğunu milletin genel kabulünden almasıdır. Siyaset, bir uzlaşı alanıdır. ... etkili bir devlet, vatandaşını tanımlayan, biçimlendiren, ona tercihler dayatan değil; vatandaşın tanımladığ denetlediği ve şekillendirdiği devlettir."

Tam da bu noktada görüldüğü gibi AK Parti siyasal perspektifini, sağc1 siyaset geleneğinde olduğu üzere Kemalist siyasete karşı olmak yerine onunla uyumluluk ile ortaya koymuştur (Kahraman, 2010: 232). AK Parti bir taraftan seçmen tabanının duyduğu ihtiyaçları karşılarken; diğer taraftan da kendisinden tedirgin olan laik seçmen kitlesinin kaygılarını uyumlulukla karşılayabilmiştir (Akdoğan, 2010: 64).

Bütün bu yaklaşımlar ise bir söylem bütünlüğü içerisinde dillendirilmiştir. Muhafazakâr demokrasi kavramı ile açıklanan yaklaşım literatürde daha önce rastlanılmayan bir ideolojik çerçeveyi de gözler önüne sermektedir.

Muhafazakâr demokratlık; Yalçın Akdoğan'ın yukarıdaki tanımlamalarından da yola çıkarak geleneksel muhafazakârlıktan ayrı tutulabilmektedir. Hatta bu ideolojik yaklaşımı, siyaset bilimciler ve bürokratlar tarafından daha çok 2007-2008 sonrasında dillendirilen (Ateş, 2014; Erler, 2007; Yanardağ, 2013; Bayraktaroğlu, 2013) ve yeni muhafazakârlık olarak adlandırılan ideolojisinin kendisi olarak nitelendirmek de yanlış olmamaktadır. Çünkü daha sonraları AK Parti içerisinde siyaset de yapan Akdoğan, kitabında muhafazakâr demokratlı tanımlarından bahsederken otoriter ve totaliter yönetime karşı duruş, kontrol altında tutulmuş ve aşamalı olarak işleyen bir değişime açık olmak, her haliyle geleneksel muhafazakârlığın 
baskıcı, değişime sırtını dönen, otoriter, bireyleri sürekli denetim altında tutmayı planlayan yönlerinden çok farklı olduğunu ifade etmiştir (2004: 15-17).

Belirtildiği üzere muhafazakâr ideolojinin radikal bakış açısının dönüştürüldüğü bir yaklaşım olarak muhafazakâr demokratlık iktidar partisi tarafından uygulanan hâkim ideoloji olarak karşımıza çıkmaktadır. Yıllarca AK Parti kadroları içerisinde yer alan ve çeşitli görevlerde bulunan Ahmet Davutoğlu ile Ali Babacan tarafindan kurulan DEVA ve Gelecek Partisi, farklı söylemler geliştirmeye çalışsa da temelde muhafazakâr ve liberal ideolojileri benimsemişlerdir. Daha çok muhafazakâr/gelenekçi yaklaşımda (medium, 2020) bulunan Gelecek Partisi'ne karşın DEVA Partisi, liberal demokrat çizgiye yakın bir tutum sergilemektedir (Independentturkish, 2020).

Yukarıda Gelecek Partisi'nin de ideolojisi olan muhafazakâr ideoloji açılanmış, temel ilkeleri sıralanmıştır. Araştırmada yeni kurulan bir siyasal parti olan DEVA Partisi'nin ideolojik söylemlerinin analizi için liberalizm ideolojisinin ve liberal demokrasinin de incelenmesi gerekmektedir.

Liberalizm temelde bireye dayalı, bireyin ekonomik ve siyasal alandaki temel hak ve özgürlüklerini koruma altına alan, serbest piyasa ekonomisinin kendi akışına bırakılmasını savunan, devletin ekonomik alana müdahalesinin sınırlı olmasını destekleyen bir siyasal doktrindir. Farklı bir tanım ise liberalizmi; özgürlük, özel teşebbüs ve mülkiyete dayalı bir piyasa sistemi olarak tasvir etmektedir (Aktan, 1996: 13). Kısaca "liberalizmin dayandığı ilkeler; bireycilik ve insan hakları, yasaların egemenliği ve sınırlı devlet, temel siyasi hak ve özgürlükler ile piyasa ekonomisidir” (Ercoşkun, 2019). DEVA Partisi’nin kurucu ilkeleri liberalizm ideolojisine dayanmaktadır. Partinin çözüm olarak sunduğu demokratik model ise liberal demokrasidir.

Liberal demokrasi, ana hatlarıyla siyasi otoritenin tek meşruiyet kaynağının genel seçimler olduğu seçimli bir demokrasi biçimidir. Siyasal eşitlik ilkesine dayanan seçimler, genel ve eşit oy verme hakkına dayanmaktadır. Bu çerçevede cinsiyet, 1rk, din, ekonomik statü ve her ne nedenle olursa olsun oy verme hakkını kısıtlayan her çeşit sistem, demokratik kabul görmemektedir. Tam anlamıyla demokrasinin sağlanması için seçimlerin yapılması, düzenli, açık ve rekabet ortamında gerçekleşmelidir. Demokratik sürecin esası halkın siyasetçilere hesap sorabilme gücü olarak görülmektedir. Siyasal akım, hareket ve partiler arasındaki şeffaf ve açık rekabetin bir sonucu olan siyasi çoğulculuk demokrasinin özüdür. Sınırlı devlet yönetimi ilkesine dayanan liberal anlayışa göre devlet, gücü kontrol edilmediği takdirde bireylere karşı her zaman baskı uygulama eğiliminde olabilmektedir. Bu sebeple devleti kontrol altına alacak anayasa, haklar, bağımsız yargı ve devlet kurumları arasında kontrol ve denge sağlayacak ilişkiler düzenlenmelidir (Heywood, 2016: 279). DEVA Partisi ideolojik söylemleri liberalizm ve liberal demokrasi ilkeleri çerçevesinde analiz edilecektir.

Böylesi bir ortamda yeni kurulan DEVA ve Gelecek Partisi'nin içerisinde görev yaptıkları ve yöneticisi oldukları iktidar partisine nasıl bir eleştiri yöneteceği, eleştirilerin konumu, durumu ve niteliği sorun teşkil etmektedir. Bu çerçevede çalışmada yeni kurulan siyasal partilerin gerçekleştirdiği ideolojik söylemlerin DEVA ve Gelecek Partisi söylemleri üzerinden incelenmesi amaçlanmaktadır.

\subsection{Araştırmanın Yöntem ve Sınırlılıkları}

Çalışmada partileşme sürecinde olan DEVA Partisi ve Gelecek Partisi'nin ideolojik söylemini çözümlemek adına yöntem olarak Foucaultcu Söylem Analizi (FSA) kullanılacaktır. FSA'nın ideolojik söylem açısından önemini kavramak için söylem analizine genel bir bakış atmak gerekmektedir.

Söylem analizinin farklı disiplinlerden (psikoloji, sosyoloji, dilbilim, antropoloji, edebiyat çalışmaları, felsefe, medya ve iletişim çalışmaları gibi) beslenerek büyüyen ve bu farklı disiplinlerin teorik çerçevesine dayanan unsurlar bezenmiş bir analiz tekniği olduğu söylenebilir (Potter ve Wetherell, 1987; Tonkiss, 2006). Söylem analizi bu açıdan bakıldığında bütünleşmiş bir tek teori, metot ve/veya uygulama değildir. Bunun aksine farklı disiplinler, farklı araştırma yaklaşımları içerisinde yürütülen, heterojen özelliklere 
sahip nitel bir araştırma yöntemidir (Tonkiss, 2006). Söylem analizi, metodolojik ve kavramsal unsurlardan meydana gelen toplumsal yaşama ilişkin bir perspektif olup, söyleme yönelik düşünme (teorik ve metateorik öğeler) ve söylemi veri haline getirme yolu olarak karakterize edilmektedir. Bu analiz yöntemi sadece daha önceki metodolojilere karşı bir seçenek olmayıp, aynı zamanda bu metodolojilerin içerisinde yer alan bakış açılarına karşı bir alternatiftir. Söylem analizi metodolojide genel, teorik ve niceliksel yaklaşımlardan, ayrı ayrı nitelendirilen, ayrıntılı ve nitel yaklaşımlara geçiş için gerekli bir analiz yöntemidir (Wood ve Kroger, 2000).

Söylem analizi, en temel tanımı ile dilin incelenmesidir. Fakat bu inceleme, ifade edilen dilsel öğelerin yalın bir incelenmesi olmayıp, dilin söze dökülenlerin sözdizimsel ve semantik karakterinin ötesine gitmeyi ve burada yatan almam ve içeriği incelemeyi gerektirmektedir. Dijk (1997)'ın da işaret ettiği gibi söylem analizi, söylem ya da dil kullanımının yalnızca biçimsel (fonetik ya da sözdizimsel) yönü ile ilgilenmemektedir. Daha çok ilgi odağını sosyal ve kültürel bağlam açısından iletişim kuran dil kullanıcılarının yarattığı sosyal olaylara çevirmektedir (Barker ve Galasinski, 2005).

Söylem analizi genel olarak dil ve söz tümcelerinin arka planındaki amaçları ortaya çıkarmaya yardımcı olmaktadır. Ancak bu yöntem yalnızca bu amaç için kullanılacak kadar yüzeysel ve sı̆̆ değildir. Söylem analizi, ideoloji ve onun inşacısı çevrelerin de amaç ve çalışmalarını çözümlemek için değerlidir.

Foucault (1972)'ya göre bireyler sadece söylem sınırlamaları içerisinde düşünebilirler. "Söylem; amaç, geleneksel destekler, güç ilişkilerinin yeniden üretilmesi ve bunların ideolojik etkilerini inşa eden ifade sistemi olarak tanımlanabilir”. Söylem analizinin merkezinde eleştiri yer alır ve söylem analizi, bu eleştirisini genelde toplumsal grupların veya bireylerin gücü elde etmek ve ideolojik görüşlerini yaygınlaştırmak için dili nasıl kullandığına çevirmektedir (Elliott, 1996).

"Söylem çözümlemesi; söylemsel pratikler, olaylar ve metinler ile daha geniş toplumsal ve kültürel yapılar, ilişkiler ve süreçler arasındaki açık ya da örtük nedensellik ve belirlenme ilişkilerini sistematik olarak araştııı". Bu tür uygulamaların, olayların ve metinlerin nasıl meydana geldiğini, iktidar ilişkileri ile iktidar mücadeleleri tarafindan ideolojik anlamda nasıl şekillendiğini; söylem ve toplum arasındaki iktidar ilişkilerinin kendisinin iktidar ve hegemonyayı sürdüren ve kuran bir faktör olarak nasıl çalıştığını ortaya koymaya yönelmektedir (Fairclought, 1993: 135).

Söylem çözümlemesinin temel ilkeleri (Fairclought ve Wodak, 1997: 271-280):

- Toplumsal sorunlarla ilgilenir.

- İktidar ilişkileri söylemseldir.

- Söylem toplumu ve kültürü inşa eder.

- Söylem ideolojik işler.

- Tarihseldir.

- Yorumlayıcı ve açıklayıcıdır.

- Toplumsal eylemin yapısidir.

"Söylem analizi, kendi doğal ortamında üretilen dili temeline almaktadır ancak, söylemlere bakılırken analiz sadece sözcüklerin düz anlam boyutunda kalmamakta, sözcükler toplumsal bağlantıları açısından da incelenmektedir" (Akar \& Mart1, 2015: 244-249). Mil (2007: 159)'e göre söylem analizi yap1lırken dikkat edilmesi gereken en önemli noktalardan biri de söylemsel verilerin homojen olma durumunun belirlenmesidir. Eleştirel söylem analizi, disiplinlerarası bir karakter göstermekte ve söylem ile toplum arasındaki bağıntıları incelemenin temeline oluşturmaktadır. Söylemin bütün boyutlarını merceği altına alırken bunu yalnızca dilsel boyutla sınırlı tutmamakta, olay ve süreçlerin iletişimsellik perspektifinden diğer boyutlarına da önem vermektedir. Bahsedilen diğer boyutlardan kastedilen ise iktidar, egemenlik, eşitsizlik ilişkilerinin söylemler aracılığıyla toplumsal düzeyde yeniden inşa edilme ve direniş gösterme pratiklerinin ele alınışıdır. Böylece eleştirel söylem analizinin temel amacı, söylemin içinde yer alan 
egemen yapıların ve ideolojilerin gizil anlamlarını ortaya çıkarmaktır. Bu anlamda eleştirel söylem analizinin özellikle manipülasyon, meşruiyet, rıza üretimi gibi bireylerin ve toplumun zihinlerini etkilemeyi hedefleyen süreçlerde söylemin işlevine yöneldiği söylenebilmektedir (Van Dijk, 1995a: 17-18).

"Söylem analizi; güç, egemenlik, hegemonya, sınıfsal eşitsizlik, cinsiyet, ırk, ideoloji, ayrımcılık, çıkar, kazanım, toplumsal yeniden üretim, dönüştürme, gelenek, sosyal yap1 ya da sosyal düzen gibi temaları öne çıkaran ve araştırma alanı olarak bu konuları işleyen söylem analizi yöntemidir". Eleștirel söylem analizi sosyo-politik güç ilişkileri, toplumsal değerler, ideolojiler, kimlik tanımlamaları gibi farklı toplumsal olguların dilsel kurgular yoluyla bireylere ve toplumsal yaşama nasıl yansıdığı ve nasıl işlendiği ile ilgilenmektedir (Van Dijk, 2003).

Özetle söylem analizi, ideolojiyi eşit olmayan güç ilişkilerinin yaratılması ve sürdürülmesinde temel belirleyici olarak görmekte ve dilin farklı toplumsal kurumlar vasitasiyla ideolojiye kaynaklık etme biçimlerine özel ilgi göstermektedir (Wodak, 2001: 2-10).

$\mathrm{Bu}$ başlık altında sunulan veriler 1şığında söylem analizinin ideolojik söylemleri çözümlemede, ideolojik güç ilişkilerini incelemede, ideolojik amaçları ortaya çıkarmada ve bunların siyasal sonuçlarını analiz etmede en uygun yöntem olduğu söylenebilir. Çalışmada gerçekleştirilecek söylem analizi ise FSA olarak belirlenmiştir.

FSA, Foucault'nun kuramlarından hareketle, yapılan söylemleri teşhis etmeyi ve bu söylemleri meydana getiren iktidar mekanizmalarını ve pratiklerini ortaya koymayı ve bütün bunların yarattığı hakikatlerin ve her türden genel kabullerin tarihsel birer kurgu olduklarının anlaşılması süreçlerini kapsayan epistemolojik bir pozisyon olarak ortaya çıkmaktadır. $\mathrm{Bu}$ genel tanımlama Foucault'nun "olaysallaştırma" (eventalization) olarak kavramsallaştırdığı düşünme ve araştırma yöntemine karşılık gelmektedir. Foucault, uygulamaların tarihsel analizini yaparak, kurgulanmış bir deneyimin bir hakikat veya saf bir zorunluluk olmadığı, aslına bakılırsa tarihsel bir kurgudan başka bir şey olmadığı sonucuna olaysallaştırma olarak adlandırdığı bir yöntem kullanarak ulaşmaktadır. Düşünüre göre "olaysallaştırma kavramı her şeyden önce doğal olduğu sanılan (self-evidence) her kabulde bir yırtılma olarak anlaşılabilir. Yani olaysallaştırma kavramı, delilik deneyiminin apaçık bir şekilde akıl hastalığı olarak kabulü; suçluların apaçık bir şekilde hapsedilmeleri gerektiğinin kabulü; hastaların bedenleri üzerinde tedavi denen uygulamaların yapılmasının kabulü gibi kabullerde bir yırtılmaya tekabül eder". Bu durum olaysallaştırmanın ilk kuramsal ve politik fonksiyonudur. İkinci fonksiyonu ise açık bir şekilde kabul edilen, evrensel, doğal, gerekli kabul edilen unsurların inşa edilmesi süreçlerindeki ilişkiler, rol oynayan güçler, stratejiler, destekler ve engeller gibi aktörlerin analizini tarihsel olarak ortaya koymak olarak karşımıza çıkmaktadır (Foucault, 2000: 226).

Foucault, söylem analizini araştırmalarında kullanmak için bir yöntem olarak geliştirmemiştir ve hatta böyle kalıplaştırılmış bir araştırma yöntemine de karşı çıkmıştır. Ancak onun yaklaşımı, herhangi bir araştırmada sorulması gereken soruları, söylemlerin tespit edilmesini, bunların etrafındaki iktidar ve direniş mekanizmalarının ortaya çıkarılmasını kapsamaktadır (Cheek, 2008: 356-357).

Willig'e (2013: 380-382) göre "anlamın olduğu her türden materyal FSA nesnesi olabilir. Sözlü-yazılı metinler, sözel olmayan davranışlar, mors alfabeleri, reklamlar, mimari yapılar, tarot kartları ve daha başka her türden anlam barındıran materyal metin olarak kabul edilir ve FSA nesnesi olabilir”. Jäger (2001: 38) FSA'nın yaşadığımız gerçekliğin söylemler yoluyla inşa edilmesindeki mekanizmaların anlaşılmasını mümkün kıldığına vurgu yaparak söylem analizinin önemini ortaya koymaktadır.

Kısaca açıklamak gerekirse iktidar ilişkilerinin, iktidarın söylemlerinin incelenmesi için önemli olan FSA, yalnızca salt iktidar durumunu değerlendirmek için değil iktidar ideolojisinin ortaya koyulması açısından da önemlidir. Yöntem tam da bu noktada iktidar partisi olan AK Parti’ye yönelik yeni kurulan DEVA ve Gelecek Partisi'nin ideolojik söylemlerinin muhalefet açısından değerlendirilmesi için en uygun yöntem olarak görülmekte ve bu araştırmada yöntem olarak kullanılmaktadır. 


\subsection{Araştırmanın Evren ve Örneklemi}

Literatür kısmında da bahsedildiği üzere yaşamı düzenleyen ve planlı söz dizimleri olan söylemin siyasal olarak kullanılması, demokrasinin gereği olan partileşme sürecinde önemli yere sahiptir. Bu süreçte partilerin kimliğinin belirlenmesi, ideolojilerinin seçmenlere duyurulması ideolojik söylemle gerçekleştirilmektedir.

Buradan hareketle partileşme sürecinde kullanılan ideolojik söylemin araştırılmasının amaçlandığı çalışmada, araştırma evrenini ülkemizde kurulan siyasal partilerin gerçekleştirdiği tüm ideolojik söylemler oluşturmaktadır. Ülkemizde her yıl onlarca siyasal parti kurulmakta ya da siyasal çalışmalarına son vermektedir. Ancak ülke genelinde örgütlenerek seçimlere katılan siyasal parti sayısı sınırlı kalmaktadır.

18 yıldır iktidarda bulunan AK Parti kadroları içerisinde yer almış ve çeşitli görevlerde bulunmuş politikacılar tarafindan kurulan DEVA ve Gelecek Partisi, iktidar politikalarına muhalif olarak siyasal yaşama müdahil olmuşlardır. Bu süreçte bu amaçla gerçekleştirilen ideolojik söylem ise çalışmanın kapsamına girmektedir. Tam da bu noktada DEVA ve Gelecek Partisi'nin kuruluş sürecinde beyan ettikleri parti programları araştırmanın örneklemini oluşturmaktadır. Parti programlarının adeta birer parti beyanı olması ve partinin bütün ideolojik ve siyasal tavrını ortaya koyması, örneklem seçiminde etkili olmuştur.

\subsection{Araştırma Hipotezleri}

Araştırmanın konusunda da bahsedildiği üzere yeni kurulan partiler olan DEVA ve Gelecek Partisi, içerisinden çıktıkları AK Parti ile ideolojik olarak benzerlikler taşısalar da kendi siyasal kimliklerini inşa etmekte ve ideolojik söylemlerini bu çerçevede gerçekleştirmektedirler. Gelecek Partisi ideolojik söylemleri daha çok muhafazakâr/gelenekçi yaklaşıma (medium, 2020) yakınken DEVA Partisi, liberal demokrat çizgiye yakın bir tutum sergilemektedir (Independentturkish, 2020).

Partileşme sürecinde gerçekleşen ideolojik söylemlerde eleştiriler daha çok iktidar partisinin politikalarının savunduğu ideolojiye uygunluğuyla ya da parti ideolojisinin kendisiyle ilgilidir. Bu durumun da göz önünde bulundurularak kurulan hipotezler şu şekildedir:

H.: DEVA Partisi ideolojik söylemi daha çok AK Parti muhafazakârliğına eleştiriler çerçevesinde inşa edilmiştir.

$\mathrm{H}_{2}$ : DEVA Partisi ideolojik söylemi daha çok liberal demokrasinin temel ilkeleri çerçevesinde inşa edilmiştir.

$H_{3}$ : Gelecek Partisi ideolojik söylemi daha çok AK Parti muhafazakârlığına eleştiriler çerçevesinde inşa edilmiştir.

$H_{4}$ : Gelecek Partisi ideolojik söylemi daha çok muhafazakârlığın temel ilkeleri çerçevesinde inşa edilmiştir.

\subsection{Araştırma Bulguları}

Yöntem kısmında sıklıkla aktarıldığı üzere örneklem olarak seçilen DEVA ve Gelecek Partisi programlarında yer alan söylemler bu başlık altında FSA ile çözümlenecektir. Her iki parti programı da ayrıntılı bir şekilde yazıldığından yaklaşık kırk başlık içermektedir. Analiz edilirken araştırmayı sistemli bir şekilde ilerletmek adına her iki parti programı da demokrasi, hukuk, siyaset, ekonomi, toplum, teknoloji, kültür sanat ve spor, güvenlik, dış politika ve çevre olmak üzere on başlık altında toplanmıştır. $\mathrm{H}_{1}$ ve $\mathrm{H}_{2}$ hipotezlerini sınamak adına ilk olarak DEVA Partisi programı ${ }^{4}$ analiz edilecektir.

\footnotetext{
${ }^{4}$ Analizde parti programının tamamı incelenmemiş, programda yer alan ifadeler hipotezlere uygunluk çerçevesinde FSA'ya dahil edilmiştir. Metinlerin bulunduğu sayfa numaraları cümlelerin sonunda yer almaktadır. Erişim Tarihi: 01.04.2020. Erişim: https://devapartisi.org/temel-metinler/parti-programi.
} 


\subsubsection{Demokrasi}

$\mathrm{Bu}$ konu başlığ1 altında özgürlükçü, katılımc1 ve çoğulcu demokrasinin temel özelliklerinden bahsedildikten sonra mevcut yönetimsel eleştiriler sıralanmıştır. Öncelikle düşünce ve ifade özgürlüğünün ceza hukukunun konusu olması eleştirilmiş ve partinin düşünce ve ifade özgürlüğü önündeki bütün engelleri kaldıracağı ifade edilmiştir. İnanç özgürlüğünün ve taleplerinin sağlanacağı, ötekileştirmenin ve inanç özgürlüğünü kısıtlayan unsurların yok edileceği vurgulanmıştır. "Kürt Sorunu” terimi kullanılmış ve insan hakları ihlallerinin giderilmesiyle birçok sorun gibi Kürt Sorunu'nun da çözüleceği belirtilmiştir. Anadilde eğitim gibi kültürel taleplerin karşılanamamasının ayrışmaları şiddetlendirdiğinden bahsedilerek evrensel hukukun temel alınacağı işaret edilmiştir. Eşit yurttaşlık, adil yargılanma ve özel hayatın güvence altına alınması garanti altına alınmıştır (s. 7-8). Görüleceği üzere yukarıda belirtilen konularla AK Parti politikaları ve uyguladığ1 muhafazakârlık eleştirilmiştir. Bunun yanında özgürlüklerin artırılacağı aktarılarak liberal demokrasinin gerekleri açıklanmıştır.

Basın ve haber alma özgürlüğünü kısıtlayan engellerin ortadan kaldırılacağı ve tarafsız ve bağımsız basının oluşturulması için gerekli çalışmaların yapılacağı programda yer almıştır. RTÜK, TRT ve Anadolu Ajansı gibi kurumların hükümetin güdümünde çıkarılacağı iddia edilmiştir (s. 11-13). Baskıcı uygulamaların son bulacağı ve özgürlükçü uygulamaların başlatılacağı vurgulanmıştır.

AK Parti ve Milliyetçi Hareket Partisi tarafından yazılan anayasaya eleştirilerde bulunulmuş ve yeni bir anayasa ile kuvvetler ayrılığının yeniden tesis edileceği, güçlü parlamenter sistemin faydalı olacağı belirtilmiştir. Mevcut anayasanın özgürlükleri kısıtladığı vurgulanmış ve Anayasa Mahkemesi’nin mevcut durumunun demokrasiye olumsuz etkileri betimlenmiştir (s. 13-16). Yine mevcut politikalar eleştirilerek toplumsal ve bireysel özelliklerin inşası iddiasında bulunulmuştur.

Siyasal partiler içerisindeki parti içi demokrasinin geliştirileceği, seçim dönemlerinde açığa çıkan şeffaflık kaygılarının giderileceği, siyaset finansmanının denetlenebilirliğinin sağlanacağı ve siyasi etik ortamının yaratılacağ 1 ifade edilmiştir. Sivil toplumun desteklenerek katılımc1 demokrasinin güçlendirileceği vurgulanmıştır (s. 16-19). Demokrasinin bireyci yönleri ortaya atılmıştır.

Açıkça saptanacă̆ gibi bu başlık altında ifade edilen eleştiriler temelde mevcut hükümet politikalarına yönelik katı uygulamalar çerçevesinde sıralanmış, daha bireyci ve özgürlükçü bir ortamın varlığı yeğlenmiştir. Böylece ideolojik söylemin AK Parti muhafazakârlığının eleştirisi ve liberal demokrasinin özgürlük vaatleri temelinde inşa edildiği söylenebilir.

\subsubsection{Hukuk}

Bu başı1ı altında adaletin yıprandığı ve toplumda adalete olan güvenin azaldığı belirtilmiştir. Adalet açlığ ve bu eksende toplumun devlete olan güven eksikliğinden bahsedilmiş, mevcut hukuk sisteminin kişilerin hak ve özgürlüğünü koruyamadığ 1 vurgulanmış, farklı inanç ve düşüncelerin mevcut hukuk sistemi ile garanti altına alınamadığı belirtilmiştir (s. 19). Mevcut katı yaklaşımlar eleştirilerek birey eksenli özgürlükler savunulmuştur.

Hukukun herkese eşit yaklaşmadığı, kişiden kişiye değiştiği iddia edilmiştir. Ülkede şu an yaşanan ekonomik krizi kaynağında da hukuktaki eksikliklerin yattığı işaret edilmiştir. İstikrarsız yargının varlığından söz edilmiş (s. 20-22), eşitlik vurgusu yapılmıştır.

Bağımsız ve tarafsız yargının inşa edileceği belirtilmiştir. Yargının en temel varlık sebebi programda yer almış ve yargı mensuplarının özlük haklarının tanınacağı belirtilmiştir (s. 23-26). Yine bu ifadelerden hareketle mevcut AK Parti muhafazakârlığının eleştirildiği, liberal demokrasinin gereği olan bireysel özgürlüğün ideolojik söylem olarak kullanıldığı söylenebilir. 


\subsubsection{Siyaset}

$\mathrm{Bu}$ konu altında son yıllarda meydana gelen sosyo-politik olaylarla yurttaş nazarındaki devlet algısının değiştiği ifade edilmiştir. Umut ve gücün kaynağı olan devletin zayıflamış, ayrımcılık, kayırma, dışlama ve ötekileştirme çalışmalarına giriştiği iddia edilmiştir. Cumhurbaşkanlığı sistemi ile bu sorunların derinleştiği vurgulanmıştır (s. 26-27). Mevcut katı politikalar eleştirilmiştir.

Kamu hizmetinin her yurttaşa eşitçe dağıtılacağından dem vurulmuştur. Merkezi otoritenin baskıcı uygulamalarının varlığından ve bahsedilen bu baskıcı uygulamaların azaltılacağından bahsedilmektedir. Yerel demokrasinin güçlendirilerek katılımcı ilkelerin tekrar yürürlüğe koyulacağı iddia edilmektedir (s. 27). Yurttaşlar arası eşitlik ve bireysel özgürlük vurgusu yapılmıştır.

Kamu personel yönetimindeki mevcut uygulamaların zararlarından bahsedilerek yönetime olumsuz etkileri olduğu belirtilmiştir. Kamu yönetiminde şeffaflık ilkesinin yeniden tesis edileceği, denetimin etkin kılınarak sorunların giderileceği ve Yolsuzlukla mücadele edileceği vurgulanmıştır (s. 28-32). Kolayca saptanacağı üzere tekrar AK Parti muhafazakârlığı eleştirilmiş, liberal demokrasinin ilkelerinin kurulacağı söylemi geliştirilmiştir.

\subsubsection{Ekonomi}

Parti tarafından uygulanacak ekonomi modelinin firsat eşitliğine dayalı, özel mülkiyeti koruma altına alan, sınırlı devlet müdahalesinin olduğu bir yapıya sahip olduğu dile getirilerek (s. 32-33) liberal demokrat ideolojinin temel dinamiklerine yer verilmiştir. Ekonominin aktörleri (Türkiye Cumhuriyeti Merkez Bankası ve Türkiye İstatistik Kurumu gibi) üzerindeki hükümet baskısının azaltılacağı ve serbest piyasa ekonomisinin uygulanacağı programda yer almıştır (s. 33-36). Böylece tutucu, muhafazakâr ideoloji eleştirilerek liberal demokrasinin gerekleri yinelenmiştir.

Ekonomi modelinde kamu kaynaklarının etkili bir şekilde kullanılacağ (s. 37) ifade edilerek piyasa için her ölçekteki özel girişimlerin destekleneceği belirtilmiştir (s. 45). Hayvancılık ve tarım, sanayi, madencilik, ulaştırma ve enerji gibi alan sektörlerinde de devlet müdahalesinin azaltılacağı ve özel girişimlerin yeğleneceği vurgulanmaktadır (s. 46-67). Burada da ideolojik söylem, mevcut uygulamalar eleştirilerek liberal ekonominin uygulanacağ 1 şeklinde gerçekleşmiştir.

\subsubsection{Toplum}

Eğitim alanında yaşanan başarısızlıklar ele alınmıştır (s. 67). Eğitimin aktörleri olan öğrenci, öğretmen ve müfredat gibi alanlarda eğitimin her kademesinde reformların gerçekleştirileceği belirtilmiştir (s. 68-78). Böylece mevcut durumlara eleştiriler getirilmiştir. Sağlik alanında reformların gerekliliği vurgulanarak sağlık çalışanlarının bireysel haklarının iyileştirileceği ifade edilmiştir (s. 79-87). Mevcut muhafazakâr yaklaşımlar eleştirilmiş, bireycilik öncelenmiştir.

Sosyal güvenliğin toplumun tamamı için uygulanacağı ve toplumda yer alan dezavantajlı gruplar olan kadın, engelli bireyler, şehit yakınları ve gazilerin sosyal haklara sahip olacağı işaret edilmiştir (s. 88-98). Böylece bireysel hak ve özgürlüklerin korunacağı belirtilerek liberal demokrasi ilkelerine ideolojik söylem unsurları yüklenmiştir.

\subsubsection{Teknoloji}

Bu konu başlığında dijital dönüşümün gereklerine yer verilmiştir. Dijital dönüşümde özel girişimlerin ön planda olması gerektiği ifade edilmiştir. Yapay zekâ, inovasyon gibi çalışmaların yalnızca devlet ve hükümet eliyle değil özel sektör eliyle de geliştirilmesi gereken unsurlar olduğu belirtilmiştir (s. 57-61). Böylece liberal ideolojinin en temel gereği olan özel girişimlerin destekleneceği programda söylem olarak yer almıştır. 


\subsubsection{Kültür, Sanat ve Spor}

Bu başl1k altında hukukun üstünlüğü, inanç ve düşünce özgürlüğü, sosyal dayanışma, bireysel özgürlük ve insan hakları gibi süreçlerin geliştiği toplumlarda kültür ve sanat etkinliklerinin geliştiği üzerinde durulmuştur (s. 104). Bahsedilen unsurlardaki gelişmelerin yeteri kadar ilerlemediğiyle muhafazakâr ideoloji eleştirilmiştir.

Kültür ve sanat alanında gerçekleşen sansür çalışmalarının kaldırılacağ ifadesi programda yerini almıştır (s. 105). Baskıcı yaklaşımlar sorgulanarak bu alanlardaki özgürlükçü yaklaşımlar ön planda tutulmuştur. Fikri hakların korunması adına "Türkiye Telif Ajansı" adı altında bir kurumun oluşturulacağı belirtilmiştir (s. 107). Bu yaklaşımın yine bireyci çalışmaları ortaya koyduğu söylenebilmektedir.

Spor alanında ise ülkemizde sporun gelişmediği iddia edilerek federasyonlar üzerinde görülen siyasal baskının bu duruma neden olduğu belirtilmiştir. Tüm spor dallarında gerçekleştirilecek kurumsal özerkliklerle bu durumun üstesinden gelineceği ifade edilmiştir (s. 102-103). Böylece liberal demokrasinin yinelediği devlet müdahalesinin azaltılması durumu ideolojik söylem olarak dile getirilmiştir.

\subsubsection{Güvenlik}

Güvenlik alanında gerçekleştirilecek çalışmaların temel insan hakkı olduğunun işaret edildiği bu başlıkta terör örgütlerinin uluslararası iş birliğiyle çökertileceği vurgulanmıştır. FETÖ gibi örgütlerden bahsedilerek bu tip örgütlerin devlete sızmalarının önleneceği iddia edilmiştir (s. 120). Burada din odaklı grupların AK Parti tarafından desteklendiği belirtilerek muhafazakârlık eleştirisi geliştirilmiştir.

Savunma sanayisinde yalnızca devlet çabalarının yanlış olduğu özel şirketlerin de milli savunmaya katkı sağlaması gerektiği işaret edilmiştir. Özel ve uluslararası şirketlerin küresel güvenlikte de etkili olduğundan bahsedilmiştir (s. 122-123).

Açıkça görüleceği üzere güvenlik ve savunma alanında da tutucu, devlet müdahalesini gerektiren politikalar eleştirilmiştir. Bu alanlardaki serbest girişimlerin desteklenerek liberal demokrasinin gereği olan devlet müdahalesinin azaltılma çalışmalarının gerçekleştirileceği söylemi ifade edilmiştir.

\subsubsection{Dıș Politika}

$\mathrm{Bu}$ başlık altında genel olarak mevcut dış politika çalışmalarının kısa vadeli ve sınırlı fayda sağlayacak şekilde yapılandırıldığından bahsedilerek bu uygulamaların eleştirildiği görülmektedir (s. 124-131). Ancak Avrupa Birliği'ne tam üyelik hedefinden bahsedilerek bu üyeliğin ticarete ve ekonomiye faydaları programa eklenmiştir (s. 127). Buradan liberal ekonominin gereklerinin söylemleştirildiği çıkarımı yapılabilmektedir.

\subsubsection{0. Çevre}

$\mathrm{Bu}$ konu başlığında çevreyi korumanın bilincinin yok olduğu ve çevre felaketlerinin arttığından bahsedilmiştir (s. 110). Deniz kirliliğe neden olan unsurlar sıralanmış, atıkların oluşturduğu kirliliklerden söz edilmiştir (s. 111). Hayvan haklarının korunamadığından bahsedilerek (s. 112) çölleşme karşıtı eylem planlarının nitelik ve niceliklerinden dem vurulmuştur (s. 113). Böylece mevcut politikalar eleştirilmiştir.

Kentleşmeyle ilgili sıkça tartışılan konular olan tarım alanlarının imara açılması, rant amacı güden politikalar, dile getirilmiştir (s. 113-114). Böylece uygulanan çalışmaların olumsuzlukları dile getirmiştir (s. 115). Akıllı şehirlerin inşası için gerekli yaklaşımlar aktarılmıştır (s. 117).

Doğal afetlerde yürütülen çalışmaların eksikliklerinden bahsedilmiştir. Bunlara karşın hayata geçirilecek çalışmaların ayrıntıları aktarılmıştır (s. 118-120). Buradan hareketle mevcut politikalara muhalefet edildiği, liberal yeni politikalar uygulanacağı söyleminin varlığından söz edilebilmektedir.

Kısaca özetlemek gerekirse DEVA Partisi programında aşağıdaki hipotezler sınanmıştır: 


\section{$H_{1}$ : DEVA Partisi ideolojik söylemi daha çok AK Parti muhafazakârlı̆̆ına eleştiriler çerçevesinde inşa edilmiştir.}

\section{$\mathrm{H}_{2}$ : DEVA Partisi ideolojik söylemi daha çok liberal demokrasinin temel ilkeleri çerçevesinde inşa edilmiştir.}

Yukarıda bahsedilen ve FSA'ya tabi tutulan on başlık altındaki ideolojik söylemlerin AK Parti tarafindan şu an uygulanan muhafazakâr politikaların eleştirisi niteliğinde olduğu ve liberal demokrat ilkelerin yeğlenmesi üzerine inşa edildiği söylenebilmektedir. Bu kapsamda sınanan $\mathrm{H}_{1}$ ve $\mathrm{H}_{2}$ hipotezlerinin kabul edildiği görülmüştür.

Araştırma bulguları başlı̆̆ının bundan sonraki kısmında Gelecek Partisi programı ${ }^{5}$ analiz edilecektir. FSA ile çözümlenecek program demokrasi, hukuk, siyaset, ekonomi, toplum, teknoloji, kültür sanat ve spor, güvenlik, dış politika ve çevre olmak üzere on başlık altında toplanmıştır. Yapılacak analizle $\mathrm{H}_{3}$ ve $\mathrm{H}_{4}$ hipotezlerini sinanacaktır.

\subsubsection{Demokrasi}

Demokrasi başlığı altında değerlendirilebilecek konularda mevcut anayasanın anti-demokratik olduğu belirtilmiştir. Anayasa değişikliği ile getirilen hükümet sisteminin (başkanlık sistemi) demokrasiye zarar verdiği eklenmiştir (s. 44-45). Merkezi yönetim anlayışındaki katı yaklaşımların sorun ürettiği, belirsizlikleri artırdığı, halkın güvenini sarstığı, liyakati ve katılımcılığı zedelediği, adalet duygusunu azalttığı, temel hak ve özgürlükleri yok saydığı iddia edilmiştir (s. 46). Bu noktada uygulanan muhafazakâr çalışmalar eleştirilmiştir.

Yukarıda bahsedilen eleştirilerden sonra merkezi yönetimde karşılaşılan hantal yapı ve eksikliklere yer verilmiştir (s. 47-50). Yerel yönetimlerde karşılaşılan demokratik olmayan çalışmalara yer verilmiştir (s. 51). Yine şu anki katı ve gelenekçi yaklaşımlar dile getirilerek uygulanan muhafazakârlığa eleştirel bir ideolojik söylem inşa edilmiştir.

Parti programında siyasi partilere yönelik kısıtlayıcı ve anti-demokratik yaklaşımlara yer verilmiştir (s. 6971). Baskıcı yaklaşımların varlığından dem vurulmuş, sivil toplumun katılım çalışmalarının engellendiği iddia edilmişti (s. 73).

Açıkça ifade edildiği üzere AK Parti tarafından uygulanan muhafazakâr yaklaşımlara yönelik tartışmalar parti programının bu konu başlığında ideolojik söylem olarak yerini almıştır. Ancak parti ideolojisi de olan muhafazakâr/gelenekçi yaklaşımların teme ilkeleri bu konu altında parti programında yerini almamıştır.

\subsubsection{Hukuk}

Parti programında ülkede meydana gelen ekonomik, siyasal ve sosyal sorunların temelinde hak ve adaletteki yozlaşmanın neden olduğu iddia edilmiştir (s. 55). Hukukun üstünlüğü yaklaşımının terk edildiği belirtilmiş (s. 56), hukuk devleti anlayışının terk edilmesinin yurttaşların adalet duygusunu alt üst ettiği ifade edilmiştir (s. 57). Kısacası yürürlükte olan adalet ve sosyal adalet şartlarının varlığı belirtilmiştir.

Kuvvetler ayrılığı ilkesinin gereklerinin yerine getirilmediği programda yerini almıştır (s. 59). Bağımsız ve tarafsız bir yargı düzeninin yürürlükte olan mevzuattan kaynaklanmadığı, yürütme unsurunun çalışmaları nedeniyle kurulamadığı belirtilmiştir (s. 60).

Kolayca ifade edileceği üzere ülkede bir adalet eksikliğinden bahsedilmektedir. Bu adalet eksikliğinin hükümetin yanlış ve katı politikalarından kaynaklandığı iddia edilmiştir. Kısaca, AK Parti muhafazakârlığı

\footnotetext{
${ }^{5}$ Analizde parti programının tamamı incelenmemiş, programda yer alan ifadeler hipotezlere uygunluk çerçevesinde FSA'ya dahil edilmiştir. Metinlerin bulunduğu sayfa numaraları cümlelerin sonunda yer almaktadır. Erişīm Tarihi: 01.04.2020. Erişim:https://wp.gelecekpartisi.net/wpcontent/uploads/2019/12/Gelecek_Partisi_Program.pdf.
} 
eleştirilmiş, ideolojik söylem bu çerçevede inşa edilmiştir; ancak Gelecek Partisi'nin de kaynağını aldığı muhafazakâr/gelenekçi ideolojinin temel ilkelerinin politikalaştırılacağından bahsedilmemiştir.

\subsubsection{Siyaset}

Siyaset başlığı altında siyasi etik anlayışının günümüz siyasal yaşamında varlığını sürdüremediğinden bahsedilerek (s. 63-64) mevcut hükümet politikalarının eleştirilmesi amaçlanmıştır. Yolsuzlukla mücadele edileceği, ülkede birçok yolsuzluk olduğu ifade edilmiştir (s. 65).

Kamu ahlâkının işlevsel unsuru olan şeffaflığın yok olduğu iddia edilerek (s. 65) AK Parti'nin muhafazakâr uygulamaları incelenmiştir. Liyakat ve işinde ehil olanların makamlara gelme düsturunun yok sayıldığı ifade edilmiştir (s. 68).

Belirtildiği üzere siyasal yozlaşma unsurları parti programında yerini almıştır. Bu yaklaşımdaki temel amacın AK Parti'yi eleştirmek olduğu söylenebilmektedir. Bu başlık altında şimdiki muhafazakâr uygulamalara eleştiri söylem olarak kullanılmıştır. Ancak muhafazakâr ideolojinin gerekleri ve temel ilkelerine yer verilmemiştir.

\subsubsection{Ekonomi}

Özellikle ülkenin 2018 yazından bugüne yaşadığı ekonomik sorunlar dile getirilerek (s. 74) temel eleştirilerle konu hakkındaki eleştirilere girişilmiştir. Bugünkü yoksullaşmanın sebepleri topluma yeterli gereçlerin verilmemesi olarak gösterilmiştir (s. 77).

Gelir adaletsizliğindeki artıştan dem vurularak muhafazakâr yaklaşımlar dile getirilmiştir (s. 82). Emekçilerin hukukunun gözetilmediği, mevcut piyasa ekonomisinin muhafaza edildiği vurgulanmış, kamu maliyesinin düzgün işletilemediği, halkın devlete emaneti olduğu ve bunun suiistimal edildiği işaret edilerek (s. 85-92) ekonomi politikaları analiz edilmiştir.

Sektörel bazda gerçekleştirilen ekonomi politikalarının toplumun yalnızca bir kısmını ekonomik olarak kalkındırdığı ifade edilmiştir (s. 93-100). Açıkça betimleneceği üzere başlığın her kısmında muhafazakâr ve uygulanan çalışmalar eleştirilmiştir; ancak çözüm noktası olarak belirtilen açıklamalarda muhafazakâr/gelenekçi ideolojinin söylemleri araçsallaştırılmamıştır.

\subsubsection{Toplum}

Bu konu başlı̆̆ında siyasetin ve toplumun öznesi olan birey de ele alınmış, bireyden hareketle toplumun odak noktası olduğu bir perspektifle ideolojik söylem ortaya koyulmuştur. Toplumda yer alan sorunların temel ve hak özgürlüklerde yaşanan kısıtlamalardan kaynaklandığı vurgulanmıştır. Toplumu oluşturan sosyal grupların din, dil, ırk, mezhep gözetilerek ayrımcılık yaşadığı iddia edilmiş, "Kürt Meselesi" terimi kullanılarak sorunun toplum temelindeki demokrasi eksikliğinden kaynaklandığı varsayılmıştır (s. 9-15). Bütün bu unsurların parti programında ideolojik söylem olarak kullanılmasındaki amaç, muhafazakâr politikaların eleştirilmesi olarak görülebilmektedir. Toplumsal meşruiyetin temeli olarak görülen özgürlükgüvenlik dengesinin yok olduğundan bahsedilerek (s. 16-18) baskıcı çalışmaların varlığı vurgulanmıştır.

Toplumda dezavantajlı gruplar olarak da bilinen kadın, çocuk, yaşlı, engelliler gibi grupların yaşadığı sorunlardan dem vurulmuştur (s. 19-38). Burada bahsedilen eksikliklerin baskıcı ve katı uygulamalardan kaynaklandığı dile getirilmiştir.

Böylece Gelecek Partisi programında bu başlık altında yer alan ideolojik söylemlerin daha çok mevcut muhafazakârlığı eleştirme odaklı inşa edildiği söylenebilmektedir. Çözüm önerisi olarak muhafazakâr ideolojinin gerekleri dile getirilmemiştir.

\subsubsection{Teknoloji}

Gelecek Partisi programında teknolojiye ait bir bölüm bulunamamaktadır. Ancak ekonomi başlığı altında Bilim, Teknoloji ve Ar-Ge'ye ait bir başlık üretim bileşeni olarak karşımıza çıkmaktadır. Bu başlık altında ar-ge yatırımlarına daha fazla destek verileceği, KOSGEB, TÜBİTAK, Sanayi ve Teknoloji Bakanlığı 
odaklı çalışmaların yetersiz olduğu belirtilmiştir (s. 100-101). Üniversite odaklı çalışmalarla çağın gereklerinin yerine getirileceği ve diğer ülkelerin teknoloji alanında yakalanacağı iddiasında bulunulmuştur (s. 102). Görüleceği üzere yine mevcut katı ve muhafazakâr politikalara eleştiri odaklı ideolojik söylemler kullanılmıştır.

\subsubsection{Kültür, Sanat ve Spor}

Gelecek Partisi programında bu başlık altında da teknoloji başlığında olduğu gibi bir bölüm bulunmamaktadır. Ancak siyasetin öznesi olan bireyin ele alındığı bölümde bu konulara değinilmiştir. Programda kültür ve sanat konusunda son yıllarda altyapı açısından önemli çalışmaların gerçekleştirildiği; fakat sonraları kısa vadeli projelere öncelik tanındığı dile getirilmiştir. Zengin kültürel ve sanatsal kaynaklara sahip Türkiye'nin bu unsurların kısıtlanması ve baskıcı politikalara maruz kalması sonucunda kültür ve sanat açısından fakirleştirildiğinden bahsedilmiştir (s. 27-28).

Spor alanında ise ülkemizin genç bir nüfusa sahip olmasına rağmen yanlış spor yatırımları nedeniyle gerekli başarıların elde edilemediği ifade edilmiştir. Sporun sağlıklı toplumu inşa eden bir özelliğinin de bulunduğunu işaret eden programda, spor federasyonlarının baskı altında tutulmasıyla sağlıklı toplumun da yaratılamadığına yer verilmiştir (s. 24-27). Kısaca değerlendirmek gerekirse yürürlükte olan muhafazakâr politikalar eleştirilerek ideolojik söylem inşasında bulunulmuştur.

\subsubsection{Güvenlik}

Ülkemizin güçlü bir savunma için daha güçlü bir orduya ve vizyoner bir savunma sanayisine sahip olmas1 gerektiği belirtilerek şu anki politikalar eleştirilmek amaçlanmıştır. Siber güvenlik, enerji kaynaklarının yeterince korunamaması ve bölgesel konular gibi hususlarda eleştiriler getirilmiştir (s. 137-139). Bu başlık altında ideolojik bir söylemden çok genel bir eleştiri geliştirilmiştir.

\subsubsection{Dış Politika}

Dış politika başlığında ülkemizde AK Parti tarafından uygulanan politikalar sıralanarak süzgeçten geçirilmiştir. Dış politikada yaşanan başarısızlıkların din, milliyet, mezhep, dil ve tarihi gelenekler ekseninde gerçekleşen tutucu, muhafazakâr uygulamaların sonucu olduğu vurgulanmıştır (s. 116-140). Bu konuda dile getirilen ideolojik söylem temelde muhafazakâr ideolojinin eleştirilmesi ile inşa edilmiştir.

\subsubsection{0. Çevre}

Çevre konusundan ülkemizde son yıllarda meydana gelen doğa tahripleri dile getirilmiştir. Bu doğa tahriplerinin temelinde hukuk devletinin ortadan kalkmasının olduğu iddia edilmiştir. Çevreyi düzenleyen dev ihalelerin belli şirketlere verildiği ifade edilerek (s. 39-44) bu tutucu, kapalı politikalar programda yerini almıştır. Görüleceği gibi yine muhafazakâr ideolojinin gerekleri eleştirilmiş; fakat partinin de ideolojisi olan muhafazakâr ideolojinin çözüm için kullanılmadığı saptanmıştır.

Kısaca özetlemek gerekirse Gelecek Partisi programında aşağıdaki hipotezler sınanmıştır:

\section{H3: Gelecek Partisi ideolojik söylemi daha çok AK Parti muhafazakârlığına eleştiriler çerçevesinde inşa edilmiştir. \\ $H_{4}$ : Gelecek Partisi ideolojik söylemi daha çok muhafazakârlığın temel ilkeleri çerçevesinde inşa edilmiştir.}

Yukarıda bahsedilen ve FSA'ya tabi tutulan on başlık altındaki ideolojik söylemlerin AK Parti tarafindan şu an uygulanan muhafazakâr politikaların eleştirisi niteliğinde olduğu söylenebilmektedir. Ancak Gelecek Partisi programında muhafazakâr ideolojini gereklerinin araçsallaştırıldığı, eleştirilere çözüm getirecek nitelikte kullanıldığı görülmemektedir. Bu çerçevede sınanan $\mathrm{H}_{3}$ hipotezinin kabul edildiği, $\mathrm{H}_{4}$ hipotezinin ise reddedildiği saptanmıştır. 


\section{SONUÇ VE DEĞERLENDİRME}

Modernleşme adımlarının atılması, siyasal katılımın toplumun tamamı tarafından benimsenmesi, kişi hak ve özgürlüklerinin yasal olarak garanti altına alınması, demokrasinin hâkim olması için gerekli unsurlardan yalnızca bazılarıdır. Yurttaşların siyasal yaşama katılması için aracı unsur olan siyasal partilerin partileşme süreci ve kurumsallaşması ise bir diğer önemli demokrasi koşuludur. Buradan hareketle DEVA Partisi ve Gelecek Partisi'nin kuruluş koşulları partileşme süreci dahilinde ortaya atılan teoriler çerçevesinde değerlendirilmiştir. Değerlendirme sonucunda her iki partinin kriz teorisi, parlamento dışında doğan partiler, kuşaksal yaş ve fonksiyon yaklaşımlarına benzer şekilde ortaya çıktıkları görülmüştür.

Siyasal partilerin kurulması ve kurumsallaşması için gerekli teorilerin yanında kullanılan ideolojik söylem de değerlidir. Kitleleri harekete geçiren fikir yapıları olan ideolojiler, yaşamı dönüştüren söylemlerle birleştiğinde ortaya çıkan ideolojik söylem partileşme sürecinde araçsallaştırılmıştır. Bu perspektifte yeni kurulan siyasal partilerin ideolojik söylemi nasıl inşa ettiği bilinmemektedir. Çalışmada partileşme sürecinde ideolojik söylemin analiz edilmesi amaçlanmıştır. Bu amaçtan hareketle DEVA Partisi ve Gelecek Partisi programı örneklem olarak seçilmiştir. Araştırma yöntemi olarak iktidar ilişkilerini ve bu ilişkilere yönelik direniş odaklarını anlamada faydalı olan FSA kullanılmıştır.

Sinanan hipotezler liberal demokratik ideolojiye sahip DEVA Partisi ile muhafazakâr ideoloji temelinde kurulan Gelecek Partisi'nin ideolojik söylemlerinin iktidar partisi olan AK Parti’ye karşı konumu ve kendi ideolojilerini dile getiriş şekilleri göz önüne alınarak aşağıdaki gibi kurulmuştur:

\section{$H_{1}$ : DEVA Partisi ideolojik söylemi daha çok AK Parti muhafazakârliğına eleştiriler çerçevesinde inşa edilmiştir. \\ $\mathrm{H}_{2}$ : DEVA Partisi ideolojik söylemi daha çok liberal demokrasinin temel ilkeleri çerçevesinde inşa edilmiştir. \\ H: Gelecek Partisi ideolojik söylemi daha çok AK Parti muhafazakârlığına eleştiriler çerçevesinde inşa edilmiştir. \\ H4: Gelecek Partisi ideolojik söylemi daha çok muhafazakârlı̆̆ın temel ilkeleri çerçevesinde inşa edilmiştir.}

Her iki parti programı da demokrasi, hukuk, siyaset, ekonomi, toplum, teknoloji, kültür sanat ve spor, güvenlik, dış politika ve çevre olmak üzere on başlık altında toplanmıştır. Bu konu başlıkları çerçevesinde gerçekleştirilen FSA sonucunda $\mathrm{H}_{1} \mathrm{H}_{2}$ ve $\mathrm{H}_{3}$ hipotezleri kabul edilmiş, $\mathrm{H}_{4}$ hipotezi ise reddedilmiştir.

Sonuç olarak partileşme sürecinde genel olarak iktidar partisine yönelik eleştirilerin varlığından söz edilmektedir. İktidar partisinin gerçekleştirdiği politikaların eksiklikleri parti programında yer almış ve mevcut uygulamaların ortaya çıkardığı yanlışlar sıralanmıştır. Bu tutum parti programına yansırken ideolojik söylem var olan iktidar partisinin temelinde bulunan ideolojiye yönelik de bir tavır olarak karşımıza çıkmaktadır. Yani eleştiri, yürütülen politikaların dayandığı ideolojiye yönelik olarak konumlandırılmıştır.

İdeolojik söylem inşasında karşımıza çıkan bir diğer yaklaşım ise uygulanan politikaların dayandığı ideolojiyi eleştirirken kurumsallaşma yolundaki partinin ideolojisini çözüm olarak sunmaktır. Yürürlükte olan politikaların ortaya çıkardığı sorunlar sıralanırken parti ideolojinin bu sorunların çözümü için uygun olduğu iddia edilmiştir.

\section{KAYNAKLAR}

Akar, D. \& Martı, L. (2015). Nitel Araştırma: Yöntem, Teknik, Analiz ve Yaklaşımlar. Anı Yayıncılık.

Akdoğan, Y. (2004). AK Parti ve Muhafazakâr Demokrasi. Alfa Yayınları. 
Akdoğan, Y. (2010). Muhafazakâr-Demokrat Siyasal Kimliğin Önemi ve Siyasal İslamcılıktan Farkı, H. Yavuz içinde, AK Parti: Toplumsal Değişimin Yeni Aktörleri (ss. 59-95). Kitap Yayınevi.

Aktan, C. C. (1996). Ekonomik liberalizmin kurucusu: Adam Smith. Yeni Türkiye Dergisi, 5(25), 546-549.

Ateş, D. (2014). Türk Dış Politikasına Giriş̧: Yeni Muhafazakârlık ve Doğu-Batı Ekseninde Yapısal Değişim. Dora Yayınevi.

Barker, C. \& Galasinski, D. (2005). Cultural Studies and Discourse Analysis: a Dialogue on Language and Identity. Sage.

Bayraktaroğlu, A. (2006), Yeni Muhafazakâr Türkiye. Arkaplan Basın Yayın.

Blommaert, J. (2005). Discourse: A Critical Introduction. Cambridge University Press.

Cheek, J. (2008). Foucauldian Discourse Analysis. (Ed.)L. M. Given, Encyclopedia of Qualitative Research Methods (ss. 356-357). Sage.

DEVA (2020). DEVA partisi programı, Ankara.

Dursun, D. (2014). Siyaset Bilimi. Beta Yayınları.

Duverger, M. (1974). Siyasi Partiler. (Çev. E. Özbudun,). Bilgi Yayınevi.

Duverger, M. (1998). Siyaset Sosyolojisi. Varlık Yayınları.

Eagleton, T. (2011). İdeoloji. (Çev. M. Özcan). Ayrıntı Yayınları.

Elliott, R. (1996). Discourse analysis: exploring action, function and conflict in social texts, Marketing Intelligence ve Planning, 14(6), 54-65.

Ercoşkun, B. (2019). Tarihsel bir perspektiften türkiye'de liberalizm. Akademik Bakış Dergisi, 1(72), 33-45.

Erler, Ö. (2007). Yeni muhafazakârlık, akp ve muhafazakâr demokrat kimliği. Stratejik Araşstırmalar Dergisi, 5(10), 126-132.

Erdoğan, M. (2014), Muhafazakârlık: ana temalar. Liberal Düşünce Dergisi, 1(2), 5-9.

Fairclough, N. \& Wodak, R. (1997). Critical Discourse Analysis. (Ed.) T. A. Van Dijk Discourse as Social Interaction (ss. 258-284). Sage.

Fairclough, N. (1993). Critical discourse analysis and the marketization of public discourse: The Universities. Discourse ve Society, 2(4), 133-168.

Foucault, M. (1987). Söylemin Düzeni. (Çev. I. Turhan). Hil Yayınları.

Foucault, M. (2000). The Essential Works of Foucault, 1954-1984, Faubion, (Ed.) J. D, Power. The New Press.

Foucault, M. (2015). Hapishanenin Doğuşu. (Çev. M. A. Kılıçbay). İmge Kitapevi.

Gelecek Partisi (2019). Gelecek partisi programı, Ankara.

Hall, S. (1998). Anlamlandırma, Temsil, İdeoloji: Althusser ve Postyapısalcı Tartışmalar, (Ed.) E. Mutlu, Kitle İletişim Kuramları. Ankara Üniversitesi İletişim Fakültesi Yayınları.

Hartley, J. (2002). Communication, Cultural and Media Studies. Routledge.

Heywood, A. (2016). Siyaset Teorisine Giriş. (Çev. H. M. Köse). Küre Yayınları.

Huntington, S. (1965). Siyasal gelişme ve siyasal bozulma. (Çev. E. Özbudun). Ankara Üniversitesi Hukuk Fakültesi Dergisi, 2 (22), 55-107.

Independentturkish (2020). Deva partisi'nin ilk gününden izlenimler: İslamcı değil merkez sağcı. İstanbul.

Jäger S. (2001). Discourse and Knowledge: Theoretical and Methodological Aspects of a Critical Discourse and Dispositif Analysis, (Ed.) R. Wodak \& M. Meyer, Methods of Critical Discourse Analysis (ss. 32-62). Sage.

Kapani, M. (2019). Politika bilimine giriş. Bilgi Yayınevi. 
Katz, R. S. \& Mair, P. (2009). Democracy and the Cartelization of Political Parties. Comparative Politics.

Kahraman, H, B. (2010), Türk siyasetinin yapısal analizi: Kavramlar, kuramlar, kurumlar. Agora Kitaplı̆̆ı.

Kıran, Z. (2001). Dilbilimine giriş. Seçkin Yayınevi.

Kirchheimer, O. (1969). Politics, law and social change. Columbia University Press.

Koole, R. (2009). Political parties: do parties still present?. Political Journal, 1(9), 105-121.

Kuru, A. T. \& Stepan, A. (2013). Bir ideal tip ve skala olarak laiklik: türkiye, fransa ve senegal karşılaştırması. (Ed.) A. T. Kuru ve A. Stephan, Türkiye'de Demokrasi, Íslam ve Laiklik (ss. 91-114), (Çev. H. Tatoğlu). İstanbul Bilgi Üniversitesi Yayınları.

Medium, (2020). Deva partisi ve Türk să̆ının geleceği. İstanbul.

Mil, B. (2007). Nitel araştırmalarda söylem analizi ve ilkeler. (Ed.) A. Yüksel, B. Mil ve Y. Bilim, Nitel Araştırma: Neden, Nasıl, Niçin?. Detay Yayıncılık.

Neumann, S. (1943). Modern Political Parties. Chicago Press.

Özbudun, E. \& Hale, W. (2010) Türkiye'de islamcılık, demokrasi ve liberalizm AKP Olayı. (Çev. E. Özbudun \& K. Göksel). Doğan Kitap.

Özipek, B. (2011). Muhafazakârlık. Timaş Yayınevi.

Portter, J. (2004). Söylemsel Psikoloji ve Söylem Analizi. (Ed.) A. Sibel, Doğunun ve Batının Yerelliği. Alfa Kitap.

Resmi Gazete (2003), 59. Hükümet programı. Ankara

Sözen, E. (1999). Söylem. Paradigma Yayınları.

Tonkiss, K. (2006). Analysis text and speech: content and discourse analysis. Sage.

Türk, B. (2003). İdeoloji. Lotus Yayınevi.

Van Dijk, T. (1989). Structures of discourse and structures of power. (Ed.) J.A. Anderson, Communication Yearbook 12. Sage.

Van Dijk T. (1995a). Discourse analysis as 1deological analysis, (Ed.) C. Schäffner ve A. Wenden, Language and Peace. Dartmouth Publishing.

Van Dijk, T. (1995b). Ideological discourse analysis. New Courant: Special Issue on Interdisciplinary Approaches to Discourse Analysis, 2(4), 135-161.

Van Dijk, T. (1995c). Aims of critical discourse analysis. Japanese Discourse, 3(1), 17- 27.

Van Dijk, T. (2000). Ideology and discourse: A Multidisciplinary Introduction. Dartmouth Publishing.

Van Dijk, T. (2003). Critical discourse analysis, D. Schiffrin, (Ed.) D. Tannen, ve E., H. Hamilton, The Handbook of Discourse Analysis (ss. 352-372). Blakwell Publishing.

Van Dijk, T. (2006). Ideology and discourse analysis. Journal of Political Ideologies, 2(11), 115-140.

Yanardağ, M. (2011), ABD ve Türkiye'deki yeni gericilik ve yeni muhafazakârlar. Ankara.

Willig, C. (2013). Introducing qualitative research in psychology. Open University Press.

Wodak, R. (2001). What CDA is about: A Summary of its history, important concepts and its developments. (Ed.) R. Wodak ve M. Meye, Methods of Critical Discourse Analysis (ss.1-13). Sage.

Wood, L.A. \& Kroger, R.O. (2000). Doing discourse analysis: methods for studying action in talk and text. Sage. 